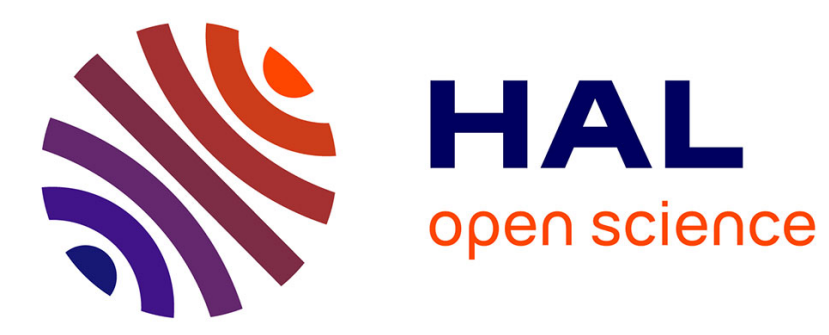

\title{
GENERAL PROVISIONS ON SUCCESSION IN THE CIVIL LAW OF UKRAINE
}

\author{
Anatoliy Kostruba
}

\section{To cite this version:}

Anatoliy Kostruba. GENERAL PROVISIONS ON SUCCESSION IN THE CIVIL LAW OF UKRAINE. Journal of the National Academy of Legal Sciences of Ukraine, 2018, 25 (4), pp.100-113. 10.31359/1993-0909-2018-25-4-100 . hal-02377762

\section{HAL Id: hal-02377762 https://hal.science/hal-02377762}

Submitted on 24 Nov 2019

HAL is a multi-disciplinary open access archive for the deposit and dissemination of scientific research documents, whether they are published or not. The documents may come from teaching and research institutions in France or abroad, or from public or private research centers.
L'archive ouverte pluridisciplinaire HAL, est destinée au dépôt et à la diffusion de documents scientifiques de niveau recherche, publiés ou non, émanant des établissements d'enseignement et de recherche français ou étrangers, des laboratoires publics ou privés. 
UDC 347.9

DOI: 10.31359/1993-0909-2018-25-4-100

Анатолій Володимирович Коструба

Кафедра иивільного права Прикарпатський національний університет імені Василя Стефаника Івано-Фр ранківськ, Україна

\title{
ЗАГАЛЬНІ ПОЛОЖЕННЯ ПРО ПРАВОНАСТУПНИЦТВО В ЦИВІЛЬНОМУ ПРАВІ УКРАЇНИ
}

\begin{abstract}
Анотація. Прийняття низки процесуальних законодавчих актів Украйни встановило нові правила процедур, головні з яких - справедливий, неупереджений та своєчасний розгляд i вирішення цивільних справ з метою ефективного захисту порушених, невизнаних або оскаржених прав, свобод чи інтересів фізичних осіб, прав та інтересів юридичних осіб, інтересів держави. Тому основна мета роботи полягає у визначенні загальних положень про правонаступництво в ичивільному праві України. Для досягнення поставленої мети було використано ряд теоретичних методів, включаючи аналіз, синтез, узагальнення, конкретизацію, порівняння. Встановлено, щчо термін «правонаступництво» не відображає змісту правових процесів, які відбуваються при зміні суб'єктивного складу циивільних правовідносин і є методологічно хибним. Таким чином, об'єктом циивільних правовідносин $\epsilon$ не тільки майно в сукупності з відповідними йому правами і обов'язками, а й майнові права, як об'єкти нематеріального світу.
\end{abstract}

Ключові слова: правонаступник, націоналізоване підприємство, юридичний обов'язок, правові відносини.

\author{
Anatoly V. Kostruba \\ Department of Civil Law \\ Vasyl Stefanyk $\rho_{\text {recarpathian National University }}$ \\ Ivano-Frankivsk, Ukraine
}

\section{GENERAL PROVISIONS ON SUCCESSION IN THE CIVIL LAW OF UKRAINE}

\begin{abstract}
The adoption of a number of procedural legislative acts of Ukraine established new rules of procedures, the main of which are fair, impartial and timely consideration and resolution of civil cases in order to protect violated, unrecognized or disputed rights, freedoms or interests of individuals, rights and interests of legal entities and interests of the state. Therefore, the main goal of the work is to determine the general provisions on succession in the civil law of Ukraine. To achieve this goal, there was used a number of theoretical methods including analysis, synthesis, generalization, concretization and comparison. It is established that the term "succession" does not reflect the content of legal processes that occur when changing the subjective composition of civil legal relations and it is methodologically incorrect. Thus, the object of civil legal relations is not only property in conjunction with its relevant rights and obligations, but also property rights as objects of the intangible world.
\end{abstract}

Keywords: legal successor, nationalized enterprise, legal obligation, legal relations. 


\section{INTRODUCTION}

Subjects of civil law, particularly, individuals in their day-to-day life, to satisfy their material and cultural needs enter into various legal relations with one another and with other subjects of civil law. Movement of legal relations starts with their establishment and ends with their termination. Within these limits legal relations exist and operate, and, besides, its effect is limited in time, but can last within a relatively shorter or longer period.

During their existence, legal relations can undergo some changes in the content or subject composition preserving its other features and continuing to exist in the changed form.

Any changes in the subjective and objective content of civil legal relations entails changes not only in subjects or objects of civil legal relations, but also changes in the content of civil legal relations, i.e. transfer of rights and obligations from one entity to another. In that case it is expedient to talk about such legal construction in the civil law as succession [1].

At transfer of the subjective right from the right grantor to the legal successor the active subject is changed in the changeable legal relations. And at transfer of civil and legal obligations from the original debtor to his successor the passive subject in legal relations is changes.

With that in mind, under transferring rights and obligations according to the procedure of civil succession it shall be understood that persons can become subjects of rights and obligations identical by the content to rights and obligations, which existed before, but between other persons, upon condition of termination of these rights and obligations of participants preceding relations and appearing new participants [2]. Thus, B. B. Cherepakhin notes that, according to the general rule, the right of the legal successor has the same content as the one of his predecessor [3].

In this case, changing the subject of legal relations entails changing of the content of civil legal relations, i.e. when changing subjects of rights in social relations regulated by law, change of those subjective civil rights and obligations, which the right grantor had, occurs. It is noteworthy that in this case not all rights and obligations of the right grantor and those, which arise in day-to-day life of persons, are transferred, but only those subjective rights and obligations arising as a result of undertaking specific legal relations.

In other words, the link between the acquired rights and obligations, and initial legal relations is the characteristic feature of succession. That being said, the right of the legal successor has the same content as the one of his predecessor. Nevertheless, depending on the personality of the legal successor, some transformation may take place [4].

\section{MATERIALS AND METHODS}

The sphere of succession is quite wide and manifold. Succession always occurs at changing the subject composition of legal relations. Thanks to legal succession the 
link between old and new legal relations exists, and owing to that exists succession in activity of old and new subjects of rights and obligations transferred [4]. To study the arguments for the goal of research, the authors applied various scientific methods.

Having classified general provisions on legal succession, the author combined, on the basis of common features, objects of legal relations. Keeping that in mind, through analysis it has been established that succession in rights and obligations has universal and singular nature, i.e. it can be common and partial. Universal succession means transfer of all rights and obligations of the predecessor to the legal successor. Meanwhile, the characteristic feature of universal succession is the fact that the predecessor carries out transfer of rights and obligations not in specific legal relations, which he participates in, but generally, in all potentially possible legal relations arising between the predecessor and third persons (legal successors). And maintaining legal relations themselves as a legal connection of two and more persons among one another in respect to specific material values. It follows thence the property and legal nature of universal succession.

Studying legal processes by means of using regulatory, structural, index and systemic methods of analysis with simulating the existing interrelations inside and outside the system allowed defining criteria for differentiation of methods of acquiring ownership rights.

It has been established that the characteristic feature of succession is the link between the acquired rights and obligations and legal relations, which continue to exist in the changed form. Change of subjects of legal relations, which is mandatory at legal succession, raises the question of identity of rights of the predecessor and rights of the successor.

\section{RESULTS}

\subsection{Analysis of the sphere of succession}

As this type of succession is characteristic of opposition between the legal predecessor and unidentified circle of persons, who may enter into civil legal relations. The characteristic example of universal succession is nationalization.

Thus, basing on extensive materials of individual and regulatory acts on nationalization of the years 1917-1919 A. V. Venediktov came to conclusion that all the property of nationalized enterprises is transferred "according to the procedure of succession from the former private enterprise (usually, a joint-stock enterprise) to the nationalized enterprise" [5]. A. V. Venediktov noted that, to some extent, the issue of the destiny of liabilities (obligations, debts) of nationalized enterprises is resolved quite distinctly. Irrespective of multiple contradictory legal acts, this issue was finally resolved by the Decree of the Council of People's Commissars of March 04, 1919 "On liquidation of obligations of state enterprises" [6], which, for all cases of 
nationalization, terminated obligations of nationalized enterprises, which arose before their transferring to the ownership of the state.

The similar nature of universal succession has succession at confiscation of property. At such transfer of property succession is manifested as accepting lawsuits of third persons regarding the ownership right to the confiscated property [7]. The state acquires the ownership right to the confiscated property only insofar as such right belongs to the person, whom such property is confiscated from. Besides, it is noteworthy that not only the ownership right to the confiscated property is transferred to the state, but also debts and liabilities of the former owner, if they arose before the respective bodies took measures to preserve the property or after taking such measures upon agreement of such bodies [7].

As can be seen from the above, at universal legal succession of the property of a person as the aggregate of rights and obligations belonging to him/her is transferred to the legal successor or legal successors as a single whole, at that in his aggregate through the single act all separate rights and obligations, which belong, at the time of succession, to the right grantor is transferred irrespective of whether they are revealed by that moment or not [4].

The same vital importance has succession in relative legal relations (binding legal relations). The characteristic feature of this type of succession is that succession in title and succession in obligations can take place each separately, or generally, in respect to arising and existing rights and obligations. Thus, the institution of cession of the right of claim (Art.512-519 of the ECU) is an example of succession in the right of claim, and the institution of debt transfer (Art.520-525 of the ECU) as an example of succession in debt and /or liabilities. On the other hand, succession may cover certain aggregates of rights and obligations. Thus, when selling a house let on lease the buyer is transferred not only the ownership right to the house, but also rights and obligations under the bilateral binding legal relations of property lease [4].

The author noted that the characteristic feature of this type of succession is its partial (singular) nature, i.e. transfer of a certain complex of rights and obligations to a third person.

\subsection{Specific features of criteria of succession}

The legal meaning of succession comes also to the fact that it is the criterion of classification of methods of acquiring ownership rights. Taking into account the nature succession of legal means of transferring rights and obligations from one persons to another, the initial methods of acquiring ownership rights shall include those, at which the ownership right arises for the first time or irrespective of will of the preceding owner. The derivatives shall also include such methods, at which acquiring ownership rights by the person in question is based on the right of the preceding owner [1]. 
In legal science there is another criterion for distinguishing methods of acquiring ownership rights.

So, O. S. Ioffe includes the right to a certain thing acquired whether for the first time or against will of its preceding owner with the initial methods of acquiring ownership rights.

The derivative method of acquiring ownership rights is characterized by the fact that in such cases the ownership right is acquired by will of the preceding owner and upon agreement of the new acquirer. Thus, O. S. Ioffe limits the initial method of acquiring ownership rights from the derivative by the will factor [8].

Nevertheless, we cannot agree with conclusions of O. S. Ioffe. They are disproven by the fact that acknowledging the will as invalid as a result of violating rights for the hereditary portion, succession occurs by law Art.1241 of the EC of Ukraine), i.e. against will of the testator [1]. Here we see that besides will of the testator occurs derivative acquiring property third person. Besides, the derivative acquiring of ownership rights with the absence of the will of the entity acquiring the property between legal entities on the grounds of administrative acts occurs. This way the will criterion of discrimination of methods of acquiring ownership rights has no realistic basis.

In view of the stated above, the author relies on the right conclusion made by B. B. Cherepakhin that the essence of acquiring the right lies not in the subjective (depending on or irrespective of will of the preceding owner), but in the objective side (in dependence of rights of the transferee on rights of the predecessor) [4].

At the same time, basic provisions on civil legal succession developed by B. B. Cherepakhin were critically analyzed by many other scientists - civilists in the USSR.

Thus, V. S. Tolstoy criticized the generally accepted view of B. B. Cherepakhin on the notion of transferring rights from one person to third persons, giving the following reasons as basic arguments:

1. rights and obligations are legal possibilities, and legal categories same as any other ideal categories cannot be transferred;

2. when transferring a thing, the ownership right of the same content, which it had with the previous owner, is not always transferred along with it - its elements might appear again (for example, when acquiring a thing from an unauthorized alienators) and vanish nowhere (for example, at acquiring the property from the state) [9].

The similar position is expressed by V. A. Belov. Studying general provisions of singular succession, the researcher has formed own position in respect to a number of questions related to the place of categories of "subjective right" and "legal liability" in the system traditionally named "legal relations".

First of all, V. A. Belov notes that rights and obligations cannot exist by themselves, irrespective of their subjects (persons). There are no rights and/or obligations, which do not belong to anybody [10]. This conclusion is justified by the scientist by 
the fact that the opposite position in respect to non-belonging of any subjective right to any person contradicts to the very nature of the subjective right, as well as the notion of legal relations as no legal relations can be even imagined without active and passive subjects. Consequently, from his point of view, it is inappropriate to affirm that there is a moment of time, when the right exists, but doesn't belong to anybody, which is the case at legal succession as transfer presupposes the existence of at least the shortest moment of time, when one person (predecessor) already transferred the right, and another (legal successor) did not accept it yet [11].

Moreover, V. A. Belov points out that the category "transfers" implies the possibility of transferring the subject of transfer not only to the authorized person, but any other person. However, as the thing, for example, can be both in lawful and unlawful (unauthorized) ownership, obviously, we cannot speak about transfer of subjective rights as the category "unauthorized" itself presupposes the persons not possessing subjective rights irrespective of the fact that certain circumstances may testify the opposite [11].

As for strictly legal arguments, V. A. Belov states that property rights are not at all the objects of civil law, which means they don't have such an important quality as transferability, i.e. they cannot be transferred from one owner to another. Arising once they shall terminate while still belonging to that person, as neither rights, nor obligations cannot change their holder [11]. The similar position is expressed by V. A. Ryasentsev [12].

So, these scientists - civilists came to the scientific conclusion that the term "succession" does not reflect the essence of legal processes taking place when changes the subject composition of civil legal relations and it is methodologically defective as it is incorrect to oppose to the objectively permanent quality something having conventional nature - a term or definition [11]. In his turn, V. A. Belov suggests to talk about "succession" as transfer of the quality of the participant of legal relations, transfer of the "place" in legal relations and inheritance in the content, merits and shortcomings of subjective rights and (or) legal obligations - "succession of the place" (change of persons) and succession of the content, but not "succession" as the essence of a legal process representing termination of some legal relations accompanied by arising new rights of another person constituting the content of new legal relations [11].

Certainly, the scientific approach developed by V. A. Belov on the basis of different points of view of other authors concerning the same problem, specifically, V. A. Ryasentsev, V. S. Tolstoy, I. B. Novitskiy, L. A. Lunets [11] and others, demonstrates the depth of the theoretical approach to the problem of civil succession, its logical structuredness. Nevertheless, in our opinion, the more argumented we consider the theory elaborated and put forward by B. B. Cherepakhin [4].

\subsection{Specific features of problems of civil succession}

Considering the problem of civil succession as a form of transfer of subjective rights (in a wide sense - also legal obligations) from persons (the right grantor) to another 
(the legal successor) according to the procedure of the derivative acquiring the right (in corresponding cases - the derivative acquiring of legal obligations) it is necessary to consider a number of the general theoretical issues concerning legal relations, particularly, the object of legal relations.

The above-mentioned is conditioned by the fact that the relevance of working on the question of what exactly consists in the object of rights, and what exactly the norm gives us the right to, is conditioned by the need to define a precise and consistent understanding in the field of succession.

As regards what exactly is the object of legal relations, in legal science there are four points of view. Let's consider them in more detail.

The concept according to which the object of legal relations is actual social relations is quite known. Such understanding of the object is based on the understanding of legal relations as a special kind of ideological attitude through which the legal norm influences the actual social relations [13].

This concept, when it is applied, for example, to the analysis of procedural relations, immediately reveals its inconsistence with the provision that all its legal relations have their object [14].

One of its founders, Yu. K. Tolstoy, being the supporter of the concept that "the object of legal relations is actual social relations" pointed out at the possibility of existence of a special object within the structure of legal relations: "acknowledging social relations as a whole the common object of legal relations does not excludes material and spiritual benefits as things or special objects of legal relations" [13].

Supporters of this concept extend the notion "object" not just to material objects and results of spiritual and intellectual work, but also people's actions, human behavior.

In opinion of supporters of this interpretation, legal relations as a social link established between people as a result of their interaction, "can affect only human behavior". Therefore, the object of civil legal relations is behavior of their subjects aimed at various material and non-material benefits. At that, it is necessary to distinguish behavior of subjects of civil legal relations in the process of their interaction with one another, and their behavior aimed at obtaining material benefits. The first one constitutes the content of civil property legal relations, and the second one - its object [15].

The theory of civil law is aware of the concept according to which under the object of legal relations an action, behavior of the obliged person (behavioristic theory of the object of legal relations) is understood. Among its active supporters are O. S. Ioffe, who distinguished between a legal object of legal relations (the object of legal reality), material (thing) and ideological one (will of participants of legal relations) [16], G. M. Genkin, who acknowledged as the object of civil and legal relations only actions or refraining from them [17], Ya. M. Magaziner [18] and others. 
Specifically, Ya. M. Magaziner points out that as legal relations are social relations - consequently, they are relations between people only, then their object is not material things, but only actions of its parties in respect to things. Even the property right is not the right to a thing, but "actions of everyone in respect to such thing", for example, adverse actions (offenses against things); that is why everyone possessing a thing belonging to another person is obliged to return it to its owner[18].

The same way, the above-mentioned meaning has the third concept of the object of legal relations, according to which things can be objects of legal relations (property theory of the object of legal relations).

In his monograph "Obligations under the Soviet civil law" M. M. Agarkov suggested: "...to avoid confusion, rationalize terminology and consider the object of right what behavior of the obliged person is directed at, first of all, a thing...; while behavior of the obliged person characterized by one or another signs (transfer of a thing, payment of money, performing certain work, refraining from committing an offense against a thing, refraining from publishing a literary work of another person and the like) is recognized as the content of legal relations" [19].

Particularly, exactly this position is expressed by V. A. Belov, who notes inadmissibility of treating the objects of civil law as property rights as they constitute the content of legal relations only, but not their object [11].

The second group of theories related to the object of legal relations admitting not just only one, but several uniform manifestations of the object of legal relations, can be consolidated into the theory of multiplicity of legal objects. Its supporters believe that "various phenomena of the external and inner world of a man can be objects of rights ..." [8], where one of such objects can be a man himself. According to the position expressed by V. M. Khvostovyi, under the object of rights shall be understood the thing directly subjected to domination of the persons possessing the respective subjective right, namely: the personality of the subject himself, a thing, an action of another person, another person, some non-material benefits and other [20].

Along with that, all the above-mentioned theories of the "object of legal relations" are not without some shortcomings, so we cannot agree with them completely.

Thus the criticism of theories seeing human behavior or a man himself as the another person exists because it is not possible to discriminate, even with the purpose of research, human behavior from human personality. While criticism of the theory seeing a man himself as the "object of legal relations", obviously shall, besides the respective specialized legal provisions, be based on common humanistic positive rights as a cultural phenomenon. The statement that a man is the "object" of right contradicts to the humanistic concept of rights and makes a human personality, whose creative potential law as one of achievements of the world culture owes its existence to, equal to phenomena of other kind, deprived of the creative potential. Given such interpretation of the legal object, inevitable shall arise the question about the subject different from the object, which a man, seemingly, can be recognized as such. The 
nature of such subject seems very vague and lies outside the legal field, but rather in the field of theology.

\section{DISCUSSION}

The most essential objections against the above-mentioned viewpoint can be formulated as a question about how behavior (actions or omissions) of people as such can respond to legal impact?

In opinion of V. I. Senchischev, one should proceed from the premise that legal relations are social relations regulated by law (legal norm), and as such it is the form of social relations, which, in their term, are the content of legal relations. Meanwhile, legal relations are not a secondary phenomenon as compared with social relations. Legal relations are relations initially constituted, created by legal norms, as, if there are no such, there is no sense to speak about legal relations irrespective whether there are real social relations or not, or whether exists something regulating them. Consequently, for legal relations not an action (behavior) is important as a phenomenon of the external world perceived by our senses, but a legal characteristic of such action or behaviour. In other words, for legal relations (and, in general, for rights) important is not an act by itself, but the objective meaning related to such act, the meaning, which it has. Its legal meaning an act of human behaviour acquires only owing to the fact that is assigned to it by a legal norm. However, the legal norm presupposes only the mandatory nature (possibility or authority) of a certain (described by norm) behaviour, but not its actual existence. And as it goes about proper conduct of an individual, then we can speak only about acts of will. And only an act of behaviour, the meaning of which constitutes the norm ("the authorized subject wants..." - an act of will; "that the obliged subject acted this way..." - according to the norm, which constitutes the meaning of an act of will), can constitute the existence. And if raise a question about which behavior exactly constitutes the "object of legal relations" (as the obligation or existence), then we inevitably come to conclusion about the possibility of existence of objectless legal relations, the very possibility of which is objected by the "behavioristic" theory: the object of legal relations, as none of two abovementioned phenomena of behaviour cannot be the "object of legal relations" [16].

An indeed, if we admit the "object" is behavior as existence, i.e. actual completed act, then the authorized subject, strictly speaking, has nothing more to demand from the subject of obligations as the act is already completed (what in a number of cases may entail termination of legal relations). Consequently, the completed act is not the "object of legal relations". As regards the proper behaviour of the obliged person, it may not follow, as the norm presupposes only the probability of certain behaviour, and the essence of claims of the authorized person consists in the fact that the obliged subject must to act in a certain way, but not in that he surely will act in a certain way. That is why one shall distinguish conduct envisaged by the norm as obligatory one from the respective norm of actual behaviour. Conduct envisaged by the norm as obligatory one (i.e. the content of the norm) can be compared with ac- 
tual behavior and conclude that it corresponds or doesn't correspond to the norm (or, rather, the content of the norm). However, conduct envisaged by the norm as obligatory one, i.e. as the content of the norm, cannot be just actual behavior corresponding to the norm.

So, the obligatory conduct constitutes the content of the norm and as such cannot be the "object of legal relations", and the existence (perfect conduct) is evaluated only according to the norm, as a result of what one can make conclusion whether the result of such conduct (act) corresponds to what the norm presupposes or not. But neither in the first, nor in the second case the legal impact is not directed at conduct, because proper conduct cannot be experienced personally, and perfect conduct can be only compared with the obligatory one (with the norm) [16].

Here it shall be noted that the criticism of the theory, according to which the "object" of legal relations is human behavior (or, more than that, - human will), can be found in one of the works of G. F. Shershenevich, where the following is said, specifically: "...obviously, a man would not seek for rights, if it only meant subjection of passive subjects to his will. This subjection to will of another is an extremely important tool, but it is not what attention of the subject is paid to. With that will, which is not expressed as an action, is not subject to legal domination. From the standpoint of law, the thing is in adhering to the established behaviour, but from the point of view of the authorized person, the thing is that he benefits from such behaviour. Just the same way, for the obliged subject the thing is not he shall do something, but in what exactly he shall do. The object of rights, certainly, cannot be other than the object of obligations as these are correlative notions. Attention of subjects, both the active and passive ones, is paid to what one acquires and another loses when conducting behavior established by law. The object of rights combines interests of the authorized and obliged subjects, and a legal attitude is the attitude of forcefully differentiated interests. The object of rights shall be sought in benefits envisaged by law as a goal and not the established behavior as a method" [21].

Thus, the object of civil legal relations is not just the property together with the respective rights and obligations, but also property rights as the objects of non-material world.

From the said above proceeds a quite logical conclusion that the content of succession is transfer of rights and corresponding obligations.

The said fact disproves the thesis of V. A. Belov and other scientists - civilists that according to the procedure of succession property rights and obligations of the parties cannot be transferred.

Furthermore, the provision saying that the category "transfer" presupposes the possibility of transfer of the subject - matter of transfer not only to an authorized person, but to any other person, first of all, the unauthorized one, is not well substantiated. There is no doubt that the legal order is based on principals of lawfulness, justice, equality of subjects of civil law and combination of social, collective and private interests, according to which all subjects of civil law act within the limits of 
certain rights transferred to them [22]. However, the possibility of not only exceeding the limits of exercising their rights, but also abusing them is not excluded. Nevertheless, in this case, one shall speak not so much about legal succession as such (as under it transfer of rights of the predecessor (the authorized person) to a third person), but rather about abusing the right or its violation. Thus, there is no legal succession as such, because nobody can transfer more rights than he/she has.

Analyzing the position of V. A. Belov further in respect to that fact that transfer of rights and obligations, according to the procedure of civil succession, inevitably entails a time interval between the moment of transfer of rights and their acceptance, and, respectively, arising objectless rights; it is noteworthy that transfer of rights and obligations from one persons to another is performed not in absentia, but upon agreement of another party to accept them when such rights ar transferred.

So, civil succession (universal or singular) represents a civil transaction. That being said, this deal has a consensual nature, i.e. it is considered to be concluded from the moment of reaching an agreement between the parties of the contract on all essential terms, according to V. A. Belov's opinion [11]. Thus, prior to the contract's conclusion on rights transfer, they are possessed by the predecessor, and since the contract's conclusion on rights transfer - by a legal successor.

It is obvious that the logical question is whether hereditary succession is a typical example of subjectless rights? As the moment of death of the legal successor creates the possibility of entering into the rights and obligations in the legal relations of the testator to the successor (heir) only after a six-month period stipulated by Article No.1298 of the Ukrainian Civil Code. And in this case, there is a period of time during the transfer of rights and obligations of the person who is no longer alive and the reception of these rights by the successor, i.e. there is created a precedent of possible subjectless rights and obligations, according to V. A. Belov's opinion.

When reasoning of this issue, one should note that the occurrence of such a legal fact as the death of a person does not mean the appearance of subjectless rights and obligations in the legal relations in which the testator participated in the existence of these subjectless rights for a certain period of time, before the adoption of the rights and obligations of the testator by the heir since the circle of persons who are new subjects of legal relations in which the testator previously participated has already been determined (1222, 1233, 1241, 1244 1260-1266 of the Ukrainian Civil Code) [23]. And for the actual implementation of the rights and obligations of the predecessor, in this case, documentary registration of the rights transfer is required. Therefore, in this period of time legal relations do not terminate, but their implementation is suspended.

Based on the above said, one should also note that succession can not mean the termination of a civil legal relations and the appearance of other ones, since, in this case, the meaning and legal role of succession as a whole are lost, as a legal structure aimed to change the subject of the legal relations without the termination of the legal relations as such. 
Succession prolongs the time of existence of legal relations, making them sustainable, thereby eliminating the uncertainty in the civil legal relations [1].

Moreover, one should note that legal relations are terminated or by the proper execution of the conditions determined by the parties of legal relations, or by other circumstances determined by Articles No. 526 and 545 of the Ukrainian Civil Code. Change of subject structure of civil legal relations can not be the basis for its termination since the legal relation exists till the moment of the goal's achievement determined at its appearance.

The same position was abided by Guliyaev A. M. Determining the essence of inheritance, he said, "With the subject's death in fact there terminate the relations that linked him with other persons regarding property as well as the his relations to this property. However, the legal relations do not terminate: they continue to exist, with the difference that the place of the retired subject is occupied now by its successor" [24].

So, of course, most of the rights and obligations shall not disappear and can not disappear with the death of a person, in their objective nature because they are rooted in legal relations that continue to exist regardless of will and case Nevertheless, it should be noted that the relations caused by personal qualities with the individual's disappearance are to stop by themselves, as without this subject they can not exist.

So, succession represents continuation of property relations, existing between the testator and subjects of the right, but already between the legal successor of the diseased and the above-mentioned subjects [25].

That is why the above-mentioned statement of V. A. Belov has strictly hypothetic nature, which has neither practical, not theoretical basis.

Besides, the legal position of V. A. Belov concerning succession in the civil law of Ukraine allowed making conclusion on legal incapacity of derivative methods of acquiring ownership rights, as well as division of succession, depending on the extent of the rights to be transferred, to universal and singular legal succession, what, in its turn, casts doubts upon the existence of the institution of property rights as a whole.

\section{CONCLUSIONS}

The stated above allows making a number of conclusions: Firstly, under objects of civil law one shall understand phenomena of the objective reality, such as things, actions, money, securitis, property rights and the like, i.e. what can correspond to the legal impact on them from the subjects of civil law.

Secondly, the rights of economic value can be the subject-matter of a transaction. They take part in the economic turnover as an object of binding relations. They include: the right to things and the right to fictions. These rights are called property rights (immaterial property), the characteristic feature of which is the possibility of their alienation by title holders. 
Thirdly, under the term "succession" one shall understand transfer of rights and obligations from one subject of civil law to another subject of civil law without changing the content and subject-matter of legal relations.

Fourthly, civil succession has a number of specific features, which are defined depending on the nature of legal relations, the subject of legal relations, the object of legal relations, the content of civil legal relations and grounds for arising of succession;

Fifthly, as a result of succession rights and obligations of the parties shall not be terminated. Only the subjects in civil legal relations change wile legal relations remain unchanged.

With the death of a person only those relations end, which were tightly connected to the person, and cannot exist without him/her neither actually, nor legally;

Sixthly, universal succession has an absolute nature and is characteristic to legal relations of ownership, while singular one has relative nature and is characteristic to binding legal relations;

Sevenly, the subject-matter of civil succession is actions of its subjects aimed at transfer rights and obligations under legal relations from one person to another;

Eightly, as succession takes place only at secondary acquiring the right, it serves as a criterion for distinction between methods of acquiring the right. Particularly, they include the initial one (at which the ownership right to the property or the property rights arises for the first time, or irrespective of rights of the preceding owner) and derivative ones (based on the right of the preceding owner).

\section{REFERENCES}

[1] Intsas, V. L. (1972). Inheritance as a special type of succession in Soviet civil law (Candidate thesis, St. Petersburg Humanitarian University of Trade Unions, Leningrad, Russian Federation).

[2] Gribanov, V. P. (1955). Legal consequences of the transfer of property under a contract of sale in Soviet civil law. Soviet State and Law, 8, 68.

[3] Cherepakhin B. B. (2001). Succession in Soviet civil law. Moscow: Statut.

[4] Hirschl, R., \& A. Shachar. Competing Orders? The Challenge of Religion to Modern Constitutionalism. The University of Chicago Law Review. Retrieved from https:// lawreview.uchicago.edu/sites/lawreview.uchicago.edu/files/07\%20Hirschl\%26Shachar_ SYMP_Online.pdf

[5] Venediktov, A. V. (1957). Organization of state industry in the USSR. Leningrad: LSU.

[6] Christina, E. (2016). Common Foreign and Security Policy: The Consequences of the Court's Extended Jurisdiction. European Law Journal, 22(4), 492-518.

[7] Code of law on requisition and confiscation of property: Resolution of the All-Russian Central Executive Committee and SNK of the RSFSR No. 149 of March 28, 1927. Retrieved from http://base.garant.ru/103918/

[8] Ioffe, O. S. (1967). Soviet civil law. Moscow: Yuridicheskaya Literatura.

[9] Tolstoy, V. S. (1973). Execution of obligations. Moscow: Nauka. 
[10] Novitsky, I. B., Luntz, L. A. (1950). General theory of commitment. Moscow: Yuridicheskaya Literatura.

[11] Belov, V. A. (2000). Singular succession in the obligation. Moscow: UKTS YurInfoR.

[12] Ryasentsev, V. A. (1955). Soviet civil law. Moscow: Nauka.

[13] Tolstoy, Yu.K. (1959). To the theory of legal relations. Leningrad: LGU.

[14] Korchevskaya, L. I. (1997). Objects of hereditary succession in the conditions of economic transformation. (Moscow State University named after MV Lomonosov, Moscow, Russian Federation).

[15] Farhang, S. (2018). Legislating for Litigation: Delegation, Public Policy, and Democracy. California Law Review, 106(5), 1529- 1529.

[16] Senchishchev, V. I. (1999). Object of civil legal relationship. In Actual problems of civil law. Moscow: Statut.

[17] Genkin, D. M. (1950). Civil law. Moscow: Gosyurizdat.

[18] Frost, A. (2018). In Defense of Nationwide Injunctions. New York University Law Review, 93(5), 1065-1119.

[19] Agarkov, M. M. (1940). Soviet Civil Law Obligations. Moscow: Yuridicheskaya literatura.

[20] Khvostov, V. M. (1997). System of roman law professor at Moscow university. Moscow: Nauka.

[21] Shershenevich, G. F. (1995). General theory of law. Moscow: Izdaniye Br. Bashmakovykh.

[22] Sverdlyk, G. A. (1985). Principles of Soviet civil law. Krasnoyarsk: Krasnoyarsk University Publishing House.

[23] Civil Code of Ukraine: Law of Ukraine of 16.01.2003. No 435-IV. Retrieved from https:// zakon.rada.gov.ua/laws/show/435-15

[24] Gulyaev, A. M. (1912). Russian civil law. St. Petersburg: Tipografiya M. M. Stasyulevic ha.

[25] Melnikova, M. P. (2001). Inheritance by law in Russia from the Code of Laws to the Civil Code of the RSFSR 1964. (historical and theoretical aspect). (Candidate dissertation, Stavropol State University, Stavropol, Russian Federation).

\section{Anatoly V. Kostruba}

Doctor of Law, Associate Professor, Professor

Department of Civil Law

Vasyl Stefanyk Precarpathian National University

76018, 57 Shevchenko Str., Ivano-Frankivsk, Ukraine

Suggested Citation: Kostruba, A. V. (2018). General provisions on succession in the civil law of Ukraine. Journal of the National Academy of Legal Sciences of Ukraine, 25 (4), 100-113.

Submitted: 09/09/2018

Revised: $16 / 10 / 2018$

Accepted: 20/12/2018 